\title{
CLEC11A Gene Product
}

National Cancer Institute

\section{Source}

National Cancer Institute. CLEC11A Gene Product. NCI Thesaurus. Code C116596.

A protein encoded by the CLEC11A gene. 